\title{
SASAT 1. \\ Hal: $43-58$ \\ PERANAN WANITA PENDAMPING SUAMI MENJALANKAN BISNIS KELUARGA DALAM PENGEMBANGAN BISNIS STUDI INDUSTRI KECIL KERUPUK DI TUNTANG KABUPATEN SEMARANG
}

\author{
Linda Ariany Mahastanti \\ Fakultas Ekonomi, Universitas Kristen Satya Wacana \\ e-mail:mahastanti@yahoo.com \\ Linda.ariany@staff.uksw.edu \\ Yeterina Widi Nugrahanti \\ Fakultas Ekonomi, Universitas Kristen Satya Wacana \\ e-mail:widi@yahoo.com
}

\begin{abstract}
The phenomenon of women working to fulfill their families' needs in times of economic crisis is very interesting. This research focused on women co-entrepreneur who cooperated with their husbands in running their business. This research has been undertaken in Tuntang Semarang. The method of collecting data utilized descriptive statistic with questionnaire and indepth interview with key persons.

Findings examined whereas women co-entrepreneurs have barrier to operate their business like season, raw materials, financial capital and managerial, they have motivation to work due to improving their family prosperity.
\end{abstract}

Keywords: women co-entrepreneur, motivasi, peran, hambatan, tuntang

\section{PENDAHULUAN}

Keterpurukan ekonomi yang dialami bangsa Indonesia akhir-akhir ini banyak membuat karyawan yang bekerja di sektor swasta kehilangan pekerjaan mereka.Hal ini mendorong masyarakat untuk menciptakan lapangan pekerjaan sendiri, dimana masyarakat mencoba untuk melepaskan diri dari ketergantungan pemerintah maupun perusahaan swasta dalam memperoleh pekerjaan. Maka muncullah usaha-usaha kecil yang tujuannya untuk menopang perekonomian keluraga yang semakin memburuk.

Usaha kecil yang mulai berkembang banyak juga didasari dari falsafah family business (bisinis kelurga). Potret mengenai usaha kecil yang pendiriannya berdasarkan bisnis keluarga ini terdapat juga di industri kerupuk daerah Tuntang Kabupaten Semarang. Industri kecil mereka kebanyakan dimulai dari keluarga, ayah sebagai pemiliknya dan anggota keluarga yang lain seperti istri, anak, dan menantu membantu dalam pengelolaan dan proses produksinya.

Fenomena yang menarik dari industri kecil di atas adalah keterlibatan istri dalam mengembangkan usaha mereka. Antara suami dan istri saling bekerjasama di dalam pengelolaan usaha sehingga berkembang cukup baik. Hal ini dapat di lihat dari semakin luasnya pasar krupuk yang mereka jangkau sampai ke beberapa daerah seperti Jakarta, Surabaya, Jogjakarta, Kalimantan, dan Sumatera. 
Dari hal di atas, perempuan mulai menunjukkan peran dalam perekonomian keluarga karena mereka bukan hanya dituntut untuk menjadi ibu rumah tanga tetapi juga harus membantu perekonomian keluarga. Lonescu (1999:13) menyatakan bahwa potret kewirausahaan perempuan yang seperti ini disebut sebagai women coentrepreneurs, dimana perempuan merupakan bagian dari pengelola usaha keluarga. Barnett (1998) dalam O'conner et. al., (2003), menifinisikan co-preneurs sebagai pasangan suami istri yang saling berbagi kepemilikan, komitmen, dan tanggungjawab untuk sebuah bisnis.

Muske et. al., (2002: 4) berpendapat bahwa alasan dari copreneurial di dalam sebuah bisnis adalah membantu berkembangnya usaha seseorang dalam menghadapi segala bentuk perubahan seperti, perubahan kondisi ekonomi, dan tehnologi. Brown (1989) menyatakan bahwa berkembangnya copreneurship saat ini merupakan salah satu sifat yang dimiliki oleh perempuan untuk memulai sebuah bisnis dengan cara bekerjasama dengan suami mereka, selain itu mereka juga dapat mengungkapkan pendapat dan mendapatkan pengalaman baru.

Sedangkan Marshall (1999: 11) menyatakan bahwa seorang Women Copreneur memiliki dua hal yang harus mereka jaga yaitu pekerjaan dan keluarga. Dengan kemampuan membangun kekuatan tim kerja yang baik, kemampuan membangun komunikasi yang mengatasi masalah dalam pekerjaan, maka seorang women co-entrepreneur dapat meraih sebuah kesuksesan dalam pekerjaan. Menurut Timmons (1994: 25), kesuksesan women co-entrepreneur ini karena tim kerja suami dan istri menyadari kelebihan dan kekurangannya masing masing dalam menjalankan bisnis kemudian saling mengisi satu sama lainya.

Di Indonesia hasil penelitian yang menyatakan bahwa posisi perempuan menjadi suatu hal yang tidak menguntungkan di
Usaha Kecil dan Menegah yang disebabkan oleh budaya, sehingga mereka menghadapi beban ganda dan jarang terlibat dalam proses pengambilan keputusan (Asian Development Bank -GFA ManajementSwiss Contact, 2000). Namun, penelitian di industri krupuk di daerah Tuntang menunjukkan hasil yang menarik. Sebagian besar usaha di industri krupuk melibatkan kerjasama antara suami dan istri dalam mengelola bisnis dan keberhasilan dari usaha mereka karena terdapat peran istri di dalamnya.

Penelitian ini mencoba mengkaji ulang hasil penelitian sebelumnya mengenai women co-entrepreneurship khususnya di daerah Tuntang kabupaten Semarang. Dimana di daerah tersebut terdapat sebuah industri kecil yang bergerak dalam produksi krupuk yang melibatkan peran istri sebagai women co-entrepreneur dalam mengelola usaha mereka.

Dalam penelitian ini juga akan dilihat apakah motivasi perempuan di industri krupuk ini sehingga mau bekerja sebagai women co-entrepreneur? Padahal secara budaya khususnya di Jawa peran istri biasanya sebagai "konco wingking" dimana mereka kurang memiliki hak dan suara untuk mengungkapkan aspirasinya. Mereka biasanya hanya menjadi seorang ibu rumah tangga saja. Oleh karena itu, motivasi bekerja para ibu rumah tangga ini apakah mereka ingin meningkatkan kesejahteraan keluarga atau ada motivasi lain yang dimiliki oleh para perempuan ini untuk mengembangkan dirinya. Mengingat saat ini peran perempuan sudah mulai diakui di keluarga.

Keterlibatan para perempuan sebagai women co-entrepreneur dalam bisnis kerupuk ini menjadi sesuatu hal yang menarik untuk melihat peran mereka dalam menjalankan bisinis bersama para suami mereka. Apakah sama dengan beberapa penelitian sebelumnya seperti di Denmark yang menyatakan peran women co- 
entrepreneur adalah untuk membantu pengelolaan keuangan (Danish Federation of Small and Medium Entreprises and breakthrough, 1998). Atau justru muncul peran yang lain mengingat kultur budaya kita berbeda dengan Denmark.

Selain itu dalam penelitian ini juga ingin dilihat hambatan apa saja yang dimiliki oleh women co-entrepreneur dalam menjalankan usahanya karena bila dilihat dari usia women co entrepreneur yang berada di Industri kecil kerupuk saat ini, mereka mumulai jenjang pendidikannya yang tidak tinggi. Ketika mereka dilibatkan dalam bisnis oleh para suami mereka, lalu hambatan apa saja yang mereka rasakan.

Setelah hambatan-hambatan dalam mengembangkan usaha oleh women coentrepreneur dapat diidentifikasi langkah selanjutnya adalah bagaimana kita membuat suatu pelatihan yang sesuai dengan kebutuhan mereka supaya pemberdayaan perempuan sebagai soeorang women coentrepreneur ini dapat ditingkatkan untuk membantu berkembangnya usaha mereka yang nantinya juga akan meningkatkan pendapatan keluarganya.

\section{KAJIAN PUSTAKA}

\section{Motivasi perempuan bekerja sebagai women co-entrepreneur}

O' Connor et. al., (2003: 605) meyatakan motivasi seorang perempuan untuk bekerja sebagai women co-entrepreneur adalah untuk meningkatkan kesejahteraan keluarga. Sedangkan alasan kenapa mereka mau bekerja dalam sebuah tim bersama suaminya adalah untuk memperoleh tambahan ilmu dan pengetahuan dari pasangan mereka sehingga dapat memberikan perubahan yang cukup besar bagi mereka.

Peran women co-entrepreneur dalam perusahaan

Peran women co -entrepreneur dalam mengembangkan usaha dari hasil beberapa penelitian terdahulu kebanyakan mengindikasikan bahwa mereka dilibatkan dalam bidang administrasi, pengelolaan keuangan dan akuntansi. Pekerjaaan tersebut cocok dikerjakan oleh perempuan karena membutuhkan tingkat ketelitian yang tinggi dan ini jarang dimiliki oleh laki-laki. Marshack (1993: 359) meyatakan jika seorang suami istri bekerjasama dalam menjalankan bisnisnya istri sering kali mengerjakan "pekerjaan perempuan" seperti bekerja di administrasi dan pengelolaan keuangan, sedangkan suami mengerjakan pekerjaan seperti pengembangan produk dan pemasaran.

Penelitian di Denmark dan Yunani meyatakan bahwa 1 diantara 5 kegitan bisnis dengan pekerja dibawah 20 orang melibatkan women co-entrepreneur (Danish Federation of Small and Medium Entreprises and breakthrough, 1998). Selain itu mereka menemukan bahwa suami sebagai pemilik melibatkan istri (women co-entrepreneur) dalam membuat keputusan bisnis. Di Denmark peran women co- entrepreneur dilibatkan dalam pengelolaan keuangan dan akuntansi sedangkan di Yunani tidak.

Di dua Negara tersebut juga ada perbedaan dalam hal waktu bekerja dan peran mereka sebagai ibu rumah tangga. Di Denmark waktu bekerja women co-entrepreneur lebih fleksible sehingga mereka dapat menyisihkan banyak waktu untuk keluarga dan kehidupan pribadinya sedangkan di Yunani tidak. Women co-entrepreneur di Denmark memliki relasi dengan rekan kerja yang lebih banyak dibandingkan dengan women co-entrepreneur di Yunani.Penelitian ini juga merekomendasikan untuk menambah pelatihan bagi women co-entrepreneur dalam bidang keuangan, Tehnologi Informasi kususnya dalam penjualan dan marketing.

Di Denmark peran women co- entrepreneur dilibatkan dalam pengelolaan keuangan dan akuntansi sedangkan di 
Yunani tidak. Di dua Negara tersebut juga ada perbedaan dalam hal waktu bekerja dan peran mereka sebagai ibu rumah tangga. Di Denmark waktu bekerja women co-entrepreneur lebih fleksible sehingga mereka dapat menyisihkan banyak waktu untuk keluarga dan kehidupan pribadinya sedangkan di Yunani tidak. Women co-entrepreneur di Denmark memliki relasi dengan rekan kerja yang lebih banyak dibandingkan dengan women co-entrepreneur di Yunani (Danish Federation of Small and Medium Entreprises and breakthrough, 1998).

Hambatan-hambatan yang dimiliki women co -entrepreneur dalam mengembangkan usaha

Penelitian sebelumnya (Centre for Enterprice and Economic Development Research (CEEDR) Mildlesex University Business Scholl, 2000) mengungkapkan bahwa selama ini women co-entrepreneur kekurangan dalam pengalaman dan kemampuan manajemen, kurangnya dukungan dari organisasi bisnis yang dapat menampung aspirasi women co-entrepreneur, kurangnya kemampuan mereka dalam menjalin relasi dengan rekan kerja dan kurangnya pengetahuan dalam bidang tehnologi informasi. Buines and Wheelock (1992: 27) dalam penelitiannya menemukan bahwa kejasama dan kepercayaan pasangan suami istri dalam mengelola bisnis di industri kecil sudah ada, tetapi istri sebagai women co entrepreneur yang selama ini juga bekerja keras untuk mengembangkan usaha kurang memiliki pengalaman dan pelatihan yang mendukung peran mereka.

Hambatan hambatan ini sering kali muncul karena kebanyakan perempuan memiliki tingkat penglaman kerja yang kurang serta jarangnya pelatihan-pelatihan yang ditujukan untuk women coentrepreneur.

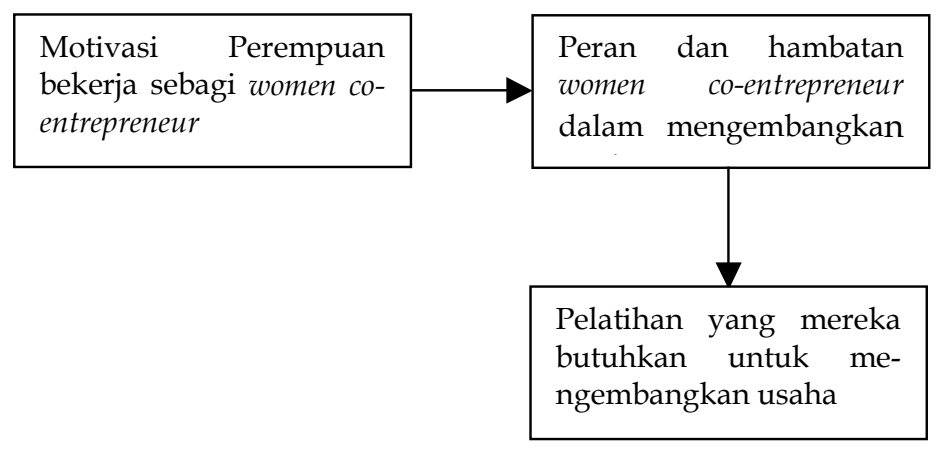

Gambar 1: Kerangka Pemikiran 


\section{METODE PENELITIAN Jenis Penelitian}

Jika di tinjau dari kegunaanya (purpose of study), penelitian ini termasuk penelitian deskriptif dan penelitian eksploratif karena dalam penelitian ini mencoba untuk menggali informasi dan menggambarkan para responden tentang apa motivasi mereka bekerja sebagai women co-entrepreneur, bagaimana peran mereka dalam mendukung perekonomian keluarga, hambatanhambatan yang dimiliki. Solusi untuk mengatasi hambatan tersebut adalah pelatihan yang disesuaikan kebutuhan mereka.

\section{Lokasi Penelitian}

Penelitian ini dilakukan di daerah Tuntang Kabupaten Semarang, Propinsi Jawa Tengah dengan populasi pengusaha kecil yang bergerak dalam industri kerupuk. Pemilihan lokasi ini didasarkan pada kondisi sosial dan perekonomian pengusaha kecil kerupuk yang bisa menggambarkan situasi penelitian. Pertimbangan lainnya adalah dari aspek kemudahan mengakses informasi (manageable). Pemilihan lokasi ini diharapkan bisa menggambarkan masalah penelitian yang telah dirumuskan

\section{Teknik Pengumpulan Data}

Data terdiri dari data primer dan data sekunder. Data primer diperoleh melalui pengamatan langsung dilapangan dengan pedoman pada instrumen penelitian menggunakan kuisoner, sedangkan data sekunder diperoleh dari berbagai laporan dan publikasi yang relevan. Pengisian kuisoner dilakukan dengan tehnik interview langsung kepada responden. Data dikumpulkan dengan teknik cross sectional dimana data dikumpulkan pada saat yang sama tetapi tempatnya yang berbeda. Disamping itu, akan diteliti juga secara mendalam (depth interview) kepada beberapa orang kunci untuk menggambarkan peranan women coentrepreneur di sana.

\section{Teknik Pengambilan Sampel}

Populasi dari penelitian ini adalah pengusaha kecil kerupuk. Unit analisis dari penelitian ini adalah pengusaha krupuk yang melibatkan istri dalam mengelola usahanya. Sampel yang akan digunakan sebagai unit analisis akan diambil dengan menggunakan tehnik purposive sampling yang bertipe judgement sampling). Tehnik ini digunakan ketika peneliti secara teliti ingin memilih anggota sampel untuk memenuhi beberapa kriteria sesuai dengan tujuan penelitian yang hendak dicapai dan untuk memenuhi kriteria gambaran populasi. (Emory dan Cooper ,1991)

\section{Tehnik Analisis}

Karena penelitian ini merupakan penelitian yang bersifat ekploratif maka dalam membut kuisoner pertanyaan yang akan diajukan bersifat terbuka. Dari hasil kuisoner tersebut kemudian diolah secara statistik deskriptif untuk mengetahui frekuensi kecenderungan jawaban dari pertanyaan. Selain itu juga dilihat analisis secara crosstab untuk melihat keterkaitan jawaban dalam kuisoner. Untuk mendukung data kuisoner penelitian ini juga menggunakan depth interview sebagai informasi tambahan dalam membuat analisis.

\section{HASIL DAN PEMBAHASAN Gambaran Objek penelitian}

Desa Tuntang merupakan salah satu wilayah di Kabupaten Semarang. Mata pencaharian penduduk Tuntang kebanyakan adalah pengusaha kerupuk. Didaerah ini terdapat dua dusun yang merupakan sentra pengusaha kerupuk yaitu Dusun Gading dan Praguman. Data pengusaha di dua dusun tersebut dapat dilihat pada Tabel 1. 
Tabel 1: Data Pengusaha kerupuk Desa Tuntang

\begin{tabular}{|c|c|c|c|c|}
\hline & \multicolumn{4}{|c|}{ TUNTANG } \\
\hline & \multicolumn{2}{|c|}{ GADING } & \multicolumn{2}{|c|}{ PRAGUMAN } \\
\hline & Kedelai & Singkong & Kedelai & Singkong \\
\hline Pengusaha & 32 & 24 & 10 & 41 \\
\hline JUMLAH & \multicolumn{2}{|c|}{56} & \multicolumn{2}{|c|}{51} \\
\hline
\end{tabular}

Sumber: data statistik desa Tuntang

Dari data tersebut dapat dilihat bahwa pengusaha kerupuk di desa Tuntang mencapai 107 pengusaha. Hampir semua pengusaha merupakan bisinis keluarga yang dikelola oleh suami dan istri. Jumlah pengusaha yang relatif banyak tersebut tidak semua dapat dikatagorikan sebagai entrepreneur, karena sebagian dari mereka adalah buruh yang hanya menjual tenaga kepada para juragan kerupuk. Mereka hanya bekerja sesuai dengan modal yang diberikan oleh juragan seperti bahan baku dan peralatan. Jumlah juragan dari semua pengusaha yang ada di Tuntang kurang lebih 50 orang. Kelimapuluh orang inilah yang nanti akan diteliti mengenai jiwa entrepreneur mereka khususnya untuk para istri yang disebut women co-entrepreneur.

\section{Data Responden}

\section{Usia}

Berdasarkan hasil kuisoner yang kami olah di dapatkan data sebagaimana tampak pada Grafik 1. Dari grafik tersebut dapat dilihat bahwa usia pengusaha kerupuk paling banyak ada pada kisaran usia 46-50 tahun sedangkan yang paling sedikit ada pada kisaran usia 56-60. Data ini mengindikasikan bahwa usia di atas 55 tahun merupakan usia yang kurang produktif bagi seorang women co-entrepreneur untuk menjalankan bisnisnya. Mendekati usia tersebut biasanya mereka mengalihkan usaha mereka pada anaknya.

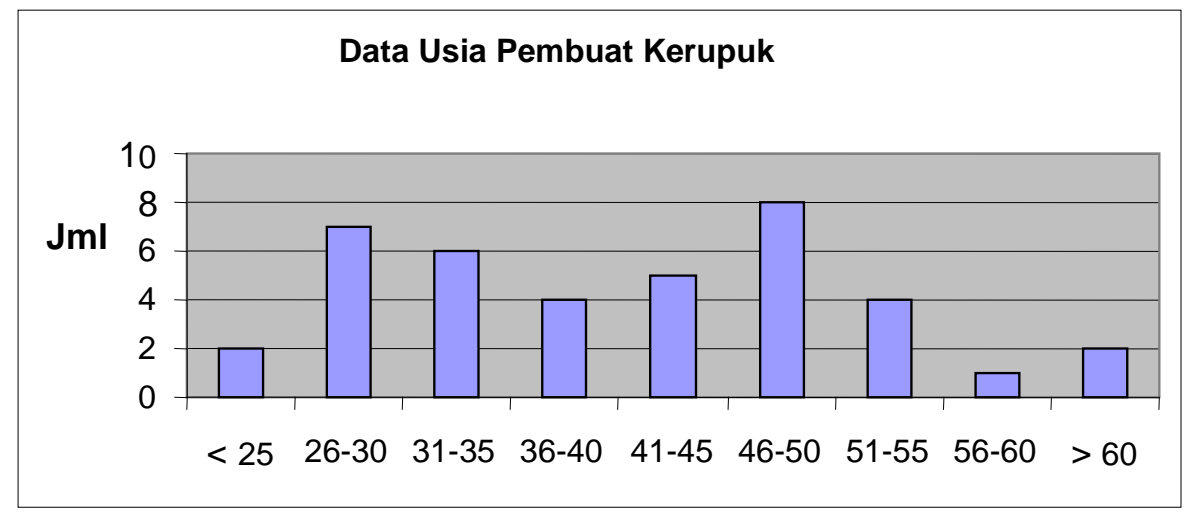

Sumber: data olahan

Grafik 1: Usia Pengusaha Kerupuk desa Tuntang Tahun 2007 


\section{Tingkat Pendidikan}

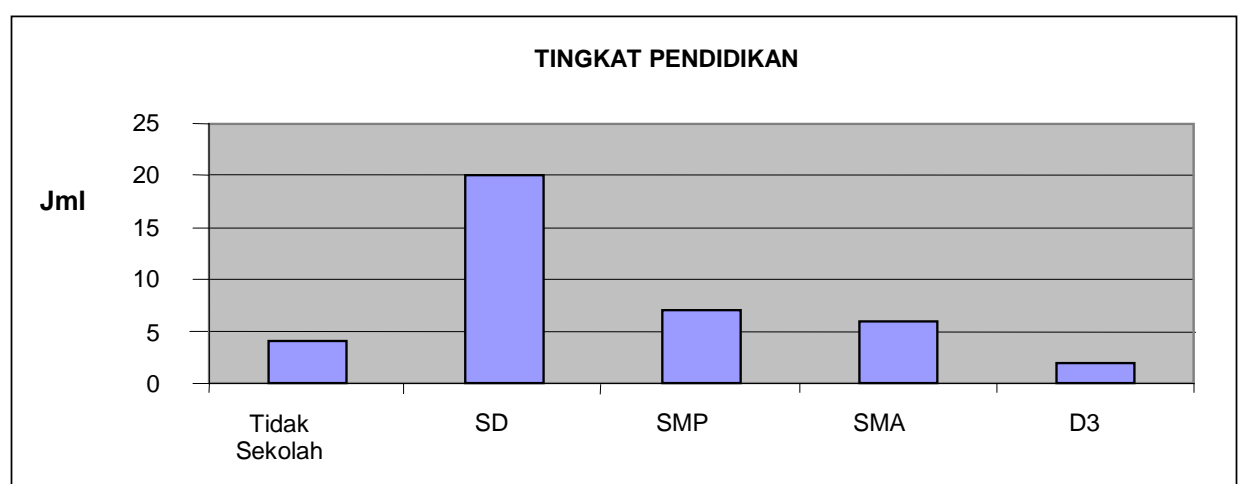

Sumber: data olahan

Grafik 2: Tingkat Pendidikan Pengusaha Kerupuk di desa Tuntang Tahun 2007

Data mengenai tingkat pendidikan para pengusaha kerupuk disajikan dalam Grafik 2. Bila dilihat dari data tingkat pendidikan pengusaka kerupuk kebanyakan tingkat pendidikan terahirnya SD sedangkan yang paling sedikit D3. Suatu hal yang menarik walaupun tingkat pendidikannya relatif rendah, tetapi para women coentrepreneur di sana dapat mengembangkan bisnis mereka dengan baik. Hal ini di duga karena mereka hanya neneruskan bisnis yang sudah dirintis oleh orang tua mereka.

\section{Lama Bekerja}

Setelah melihat karakteristik responden dari usia dan tingkat pendidikan, pada Grafik 3 berikut ini disajikan data mengenai lama mereka bekerja.

Dari data tersebut dapat dilihat paling banyak mereka bekerja sudah sekitar 11-15 tahun. Jangka waktu ini menandakan bahwa mereka sudah cukup lama bergerak di usaha ini. Sehingga diharapkan jiwa entrepreneur mereka semakin terasah.

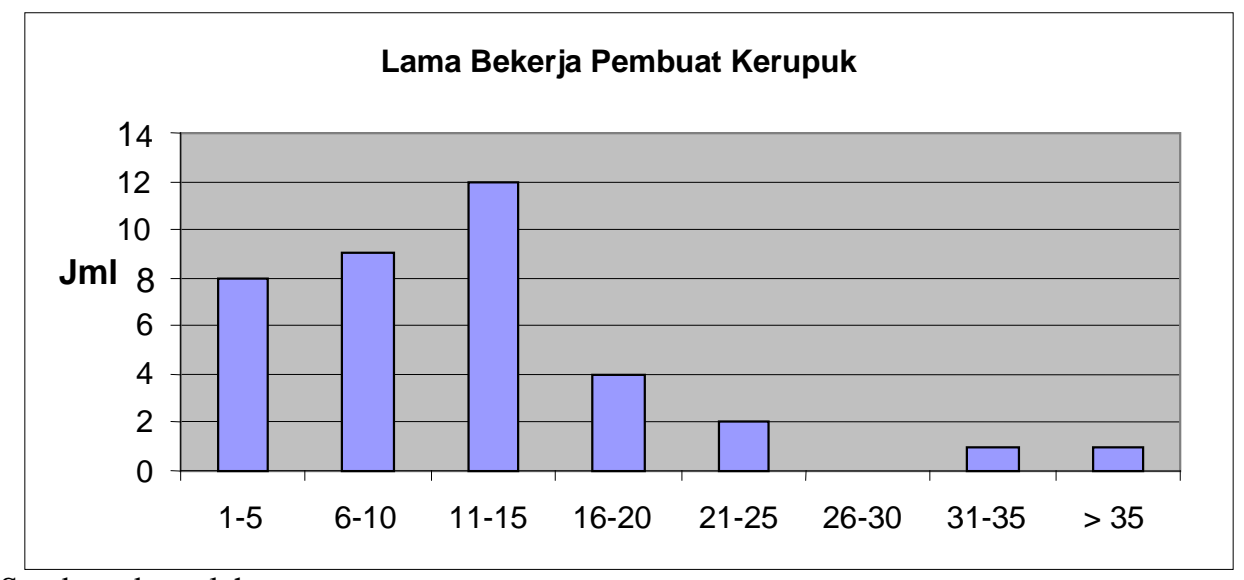

Sumber: data olahan

Grafik 3: Lama Bekerja Pengusaha Kerupuk tahun 2007 


\section{Analisa Data dan Pembahasan Motivasi}

Motivasi merupakan salah satu hal yang menarik untuk dilihat dari karakteristik seorang women co-entrepreneur di Pengusaha kerupuk desa Tuntang ini. Menurut O' Connor et. al., (2003:605) motivasi utama seorang women co-entrepreneur adalah untuk meningkatkan kesejahteraan keluarga. Sedangkan alasan bekerjasama dengan suaminya adalah untuk mendapatkan tambahan ilmu dan pengetahuan dari pasangan mereka. Sedangkan motivasi seorang women co-entrepreneur di Tuntang dapat dilihat pada Grafik 4.

Bila dilihat dari grafik tersebut dapat dilihat bahwa motivasi seorang women coentrepreneur di Pengusaha kerupuk desa Tuntang sebagian besar adalah untuk meningkatkan kesejahteraan keluarga. Hal ini selaras dengan penelitian O'Cannor et. al., (2003).Berbeda dengan hasil penelitian O'Cannor yang mengatakan bahwa motivasi lain dari women co-entrepreneur bekerja sama dengan suaminya adalah memperoleh tambahan ilmu dan pengetahuan dari para suami hal ini tidak terjadi. Hal ini bisa diduga sebagian besar women coentrepreneur di pengusaha kerupuk Tuntang berlatang belakang pendidikan yang rendah kebanyakan mereka hanya lulusan SD. Sehingga pengetahuan bagi mereka tidaklah begitu penting. Yang terpenting bagaimana mereka dapat mencukupi kebutuhan hidupnya dari berdagang kerupuk. Selain itu latar belakang budaya jawa yang mengatakan bahwa istri menjadi "konco wingking" suami membuat mereka tidak bisa sharing pengetahuan dengan para suami.

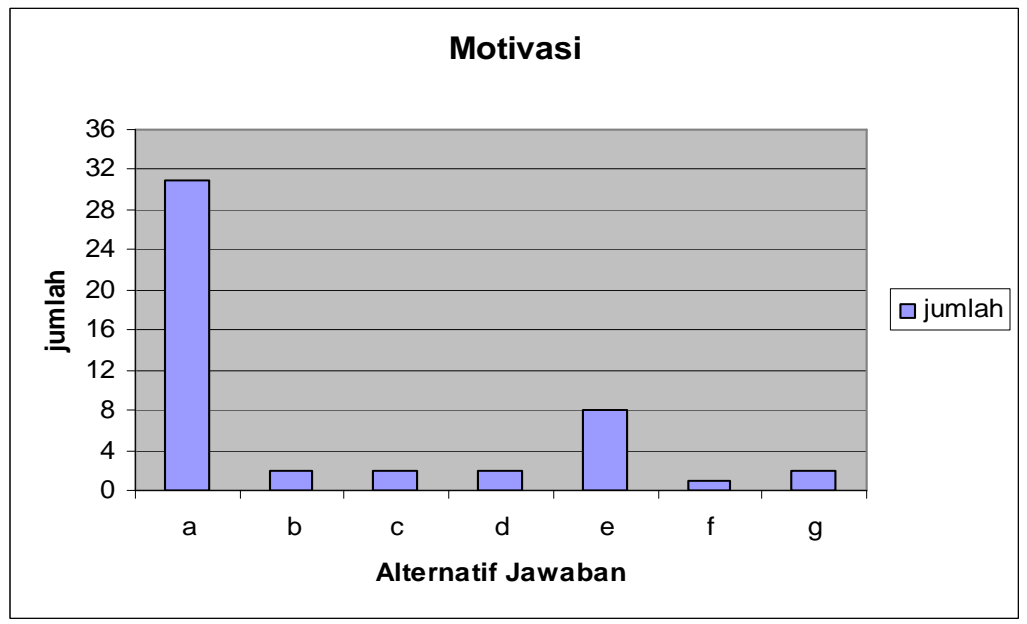

Sumber: data olahan

Grafik 4: Motivasi women co-entrepreneur di Pengusahan kerupuk Desa Tuntang

Keterangan:

A : Meningkatkan kesejahteraan keluarga

B : memperoleh tambahan ilmu dari suami

C : Menciptakan kebersamaan dengn suami

D : Pengembangan diri

E : Ikut-ikutan tetangga 
Sedangakan motivasi kedua mereka berusaha kerupuk adalah ikut-ikutan tetangga. Tatangga yang berhasil dalam menjalankan bisinis mereka, menjadi motivasi para women co-entrepreneur untuk berusaha. Jika dilihat dari domisili mereka berusaha yaitu dusun Gading dan Praguman, daerah ini merupakan sentra pengusaha kerupuk. Oleh karena itu hampir semua warganya mencari nafkah di industri ini sehingga wajar jika keberhasilan tetangga menjadi motivasi mereka untuk berusaha sebagai women co-entrepreneur.

\section{Peran}

Apa saja yang women co-entrepreneur lakukan di usaha mereka menjadi sesuatu yang menarik untuk dikaji lagi. Marshack (1993:359) dalam penelitiannya mengatakan bahwa jika suami dan istri bekerja sama dalam menjalankan bisnisnya istri sering kali mengerjakan "pekerjaan perempuan" seperti administrasi dan pengelolaan keuangan, sedangakan suami bekerja sebagai pengembang produk dan pemasaran. Menurut Danish Federation of Small and Medium Entreprises (1998) menyatakan di Denmark istri lebih dilibatkan pada pengelolaan keuangan dan akuntansi, serta menjalin relasi dengan rekan kerja sedangkan di Yunani tidak. Bagaimana dengan women co-entrepreneur di pengusaha kerupuk Tuntang? jawabannya bisa dilihat pada grafik berikut ini:

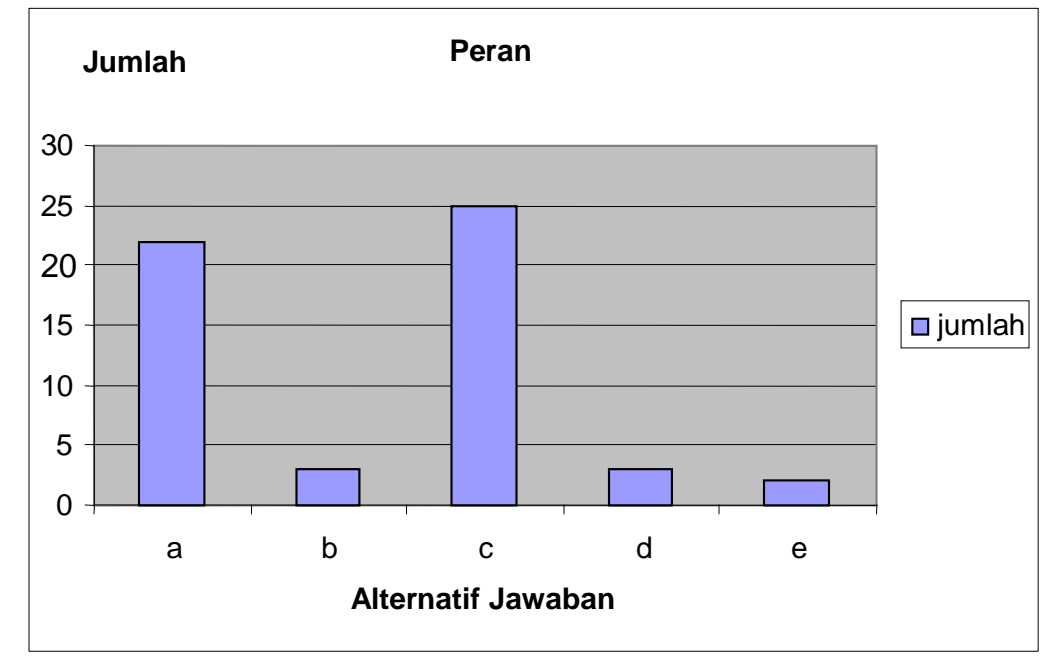

Sumber: data diolah

Grafik 5: Peran Women co-entrepreneur di usaha Kerupuk desa Tuntang

Keterangan:

A : Administrasi dan pengelolaan keuangan

$\mathrm{B}:$ menjalin relasi dengan rekan kerja

C : Produksi

D : Pemasaran

E : lainnya 
Menurut para women co-entrepreneur di Tuntang peran yang selama ini mereka jalankan adalah dibagian produksi dan mengelola administrasi serta keuangan. Hal ini sejalan dengan penelitian Marshack (1993: 359) dan Danish Federation of Small and Medium Entreprises (Anonymous, 1998) untuk hal administrasi dan pengelolaan keuangan, karena secara psikologis perempuan lebih ahli dan teliti dalam bidang ini. Agak berbeda dengan penelitian Marshack (1993), yang mengatakan bahwa peran produksi dipegang oleh para suami. Di Usaha kerupuk ini tidak terjadi demikian, justru para istri yang berperan. Hal ini dikarenakan dari jenis industri yang ditekuninya. Untuk proses produksi kerupuk para perempuan lebih berperan dalam hal memberikan rasa/bumbu. Menurut budaya Jawa perempuan memang bertugas untuk hal dapur seperti ini.
Untuk melihat lebih jauh lagi tentang karakteristik Women co Entrepreneur di Tuntang akan dilihat analisis secara crosstabs antara tingkat pendidikan dan peran yang mereka jalankan, table crosstabs peran dan tingkat pendidikan dapat dibaca pada Grafik 6.

Grafik tersebut menggambarkan bahwa semakin tinggi tingkat pendidikan mereka maka peran yang dijalankan lebih terfokus pada bidang A (administarsi dan pengelolaan keuangan, sedangkan semakin rendah tingkat pendidikan mereka peran yang dijalankan hanya di bidang $\mathrm{C}$ (produksi). Dari sini bisa dilihat bahwa pengetahuan yang didapatkan dari bangku sekolah mempengaruhi mereka didalam menjalankan peran. Semakin sulit peran yang harus mereka jalankan tingkat pendidikan yang dibutuhkan juga semakin tinggi.

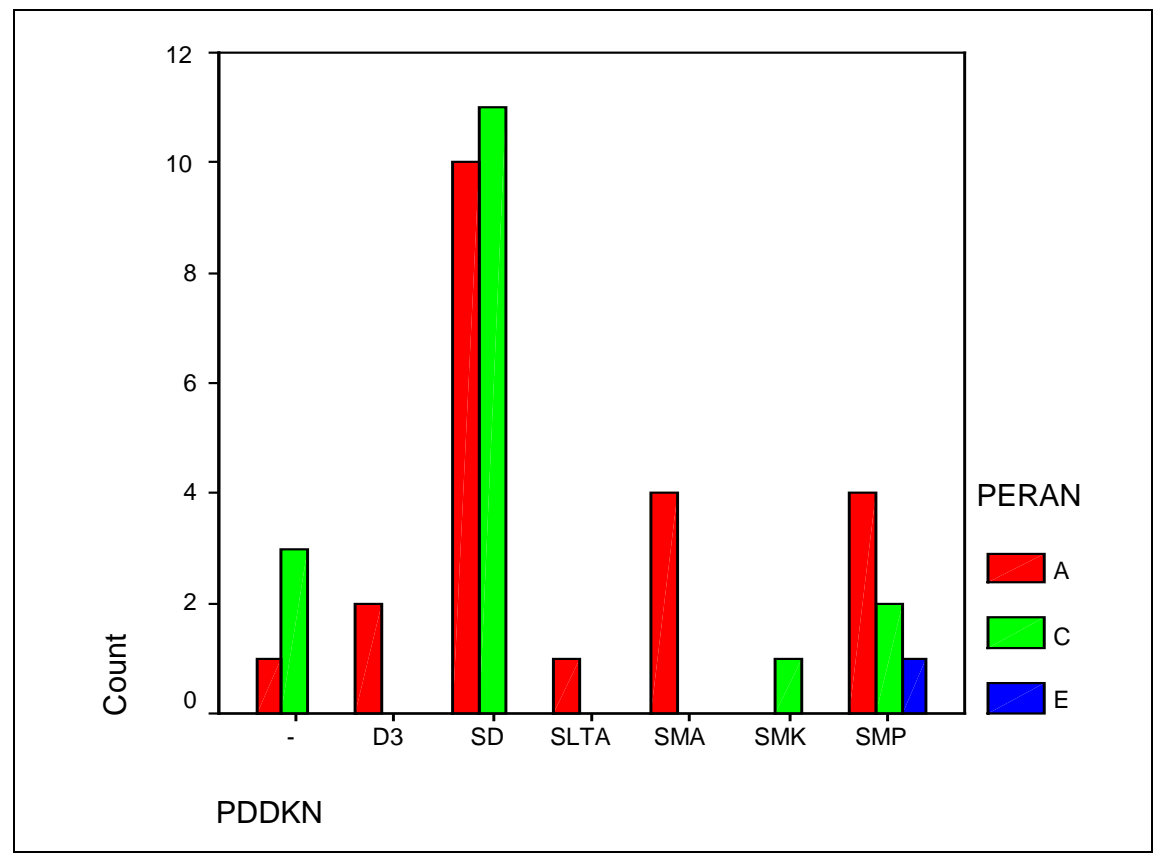

Sumber: data olahan

Grafik 6: Analisis Crosstabs antara Peran dan Tingkat Pendidikan 


\section{Hambatan}

Untuk menjalani peran yang selama ini mereka lakukan ada beberapa hambatannya. Seperti yang dikemukakan oleh Centre for Entreprise and Economic Development Research (CEEDR) Mildlesex University Business School (Anonymous, 2000) dalam penelitiannya yang mengungkapkan bahwa Women co-entrepreneur memiliki hambatan dalam pengalaman dan kemampuan manajemen. Hal ini disebabkan dari kurangnya dukungan dari organisasi bisnis. Selain itu mereka juga memiliki hambatan dalam bidang menjalin relasi dengan rekan kerja dan kurangnya pengetahuan tentang teknologi informasi. Wheelock (1992) juga mengatakan bahwa hambatan para perempuan ini karena kurangnya pengalaman dan pelatihan. Hambatan juga di alami oleh para ibu rumah tangga yang membantu suaminya di Usaha Kerupuk Tuntang. Grafik 7 menyajikan hambatan yang selama ini mereka rasakan. Hambatann yang dialami oleh women co-entrepreneur kerupuk Tuntang ini ternyata cukup jauh berbeda dari hasil dua penelitian sebelumnya. Hambatan yang mereka utarakan kebanyakan berkaitan dengan mahalnya harga bahan baku yang mereka harus beli. Seperti bahan baku kedelai yang semula harganya $\mathrm{Rp} 4.250 / \mathrm{kg}$ sekarang menjadi Rp5.500/kg sedangkan mereka tidak berani untuk menaikkan harga jualnya. Karena akhir-akhir ini kerupuk mereka tidak begitu laku yang diakibatkan dari naiknya harga minyak goreng. Kendala ini sangat dirasakan betul oleh para co entrpreneur ini karena tugas mereka di bagian produksi.

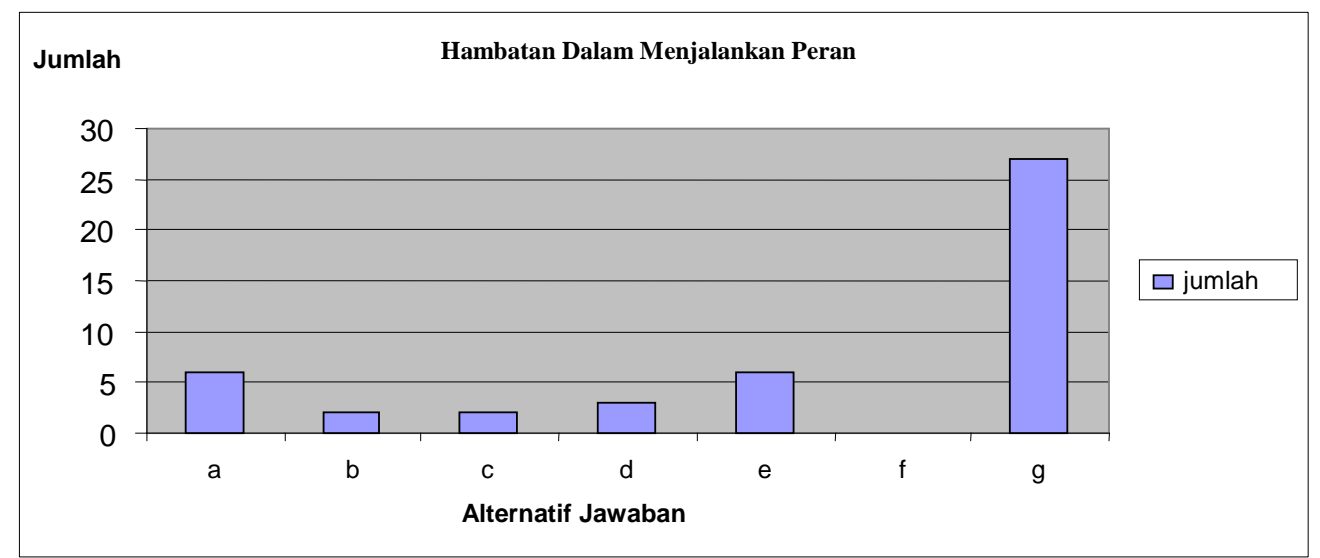

Sumber: data olahan

Grafik 7: Hambatan women co-entrepreneur di Usaha kerupuk Tuntang

Keterangan:

A : kurangnya dukungan organisasi bisnis

B : menjalin relasi dengan rekan kerja

C : Pengetahuan tentang Tehnologi Informasi

D : Kemampuan manajemen

E : Kurangnya Pelatihan

$\mathrm{F}$ : kurangnya dukungan keluarga

G : Lainnya 
Musim juga menjadi salah satu faktor yang menghambat mereka untuk berproduksi, karena selama ini mereka hanya mengandalkan panas matahari untuk mengeringkan kerupuk. Beberapa pengusaha kerupuk mengemukakan bahwa mereka mendapat bantuan oven dari pemerintah untuk pengeringan, tetapi hal ini tidak mengungtungkan karena biaya produksi menjadi lebih tinggi.

Namun demikian, melihat grafik 7 di atas, semua responden tidak ada yang menjawab point $\mathrm{f}$ yaitu kurangnya dukungan keluarga. Ternyata mereka tidak mengalami yang namanya Triple Burden Women. Keluarga sepenuhnya mendukung para perempuan ini bekerja dan mereka masih bekerja dilingkungan rumahnya. Biaya produkasi yang semakin mahal jika tidak di ikuti oleh mudahnya akses modal. Walaupun modal menjadi kendala mereka ada satu hal yang menarik bahwa mereka tidak mau mencukupi kebutuhan modalnya dengan berhutang kepada bank. Padahal selama ini sudah banyak bank yang menawarkan jasa kredit kepada mereka. Faktor ketidak beranian ini diakibatkan dari budaya mereka yang takut untuk mengambil risiko membayar angsuran setiap bulannya. Mereka mengumpamakan seperti "nyunggi kompor ning sirah". Hal ini sebetulnya tidak perlu terjadi jika mereka mendapatkan penyuluhan yang benar mengenai berhutang dan bagaimana mensiasati angsuran supaya tidak memberatkan.

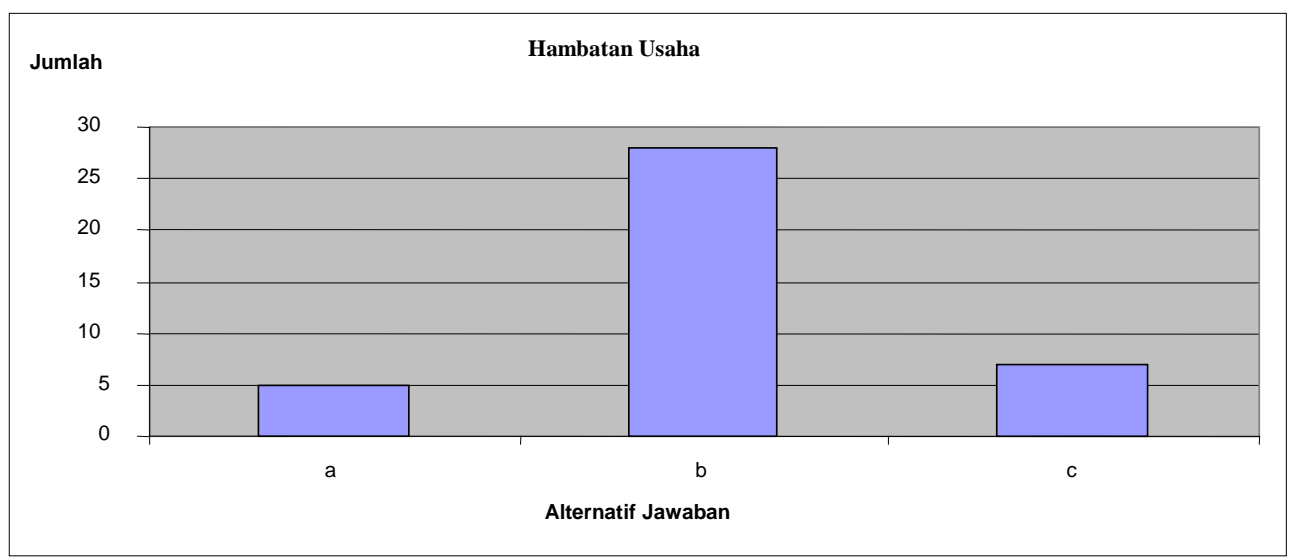

Sumber: data olahan

Grafik 8: Hambatan Usaha Women co-Entrepreneur di Tuntang

Keterangan:

a. Pemasaran

b. Akses Modal

c. Lain-lain 
Untuk melihat lebih dalam lagi mengenai hambatan ini, maka akan dilihat analisis secara crosstabs antara hambatan dan lama bekerja women co-entrepreneur. Apakah ada fenomena yang berbeda berkaitan dengan dua hal tersebut.

Berdasarkan Grafik 9 di bawah dapat dilihat bahwa lama bekerja seorang women co-entrepreneur antara 14-15 tahun memiliki hambatan pada poin G (lain-lain) seperti bahan baku, serta factor musim. Diduga hal ini diakibatkan dari kurangnya pengalaman mereka dalam bidang industri kerupuk ini seperti bagaimana mensiasati pengeringan kerupuk jika musim hujan tiba, ataupun bagaimana mereka mencari bahan baku yang dapat dijangkau harganya. Sedangkan semakin lama mereka bekerja di industri ini hambatan yang dimiliki justru lebih kepada aspek manajerial (D) untuk rata-rata lama bekerja 50 tahun. Kemungkinan ini disebabkan dari tingkat pendidikan para women co- entrepreneur untuk lama bekerja 50 tahun ini yang ratarata lulusan SD atau bahkan tidak bersekolah.

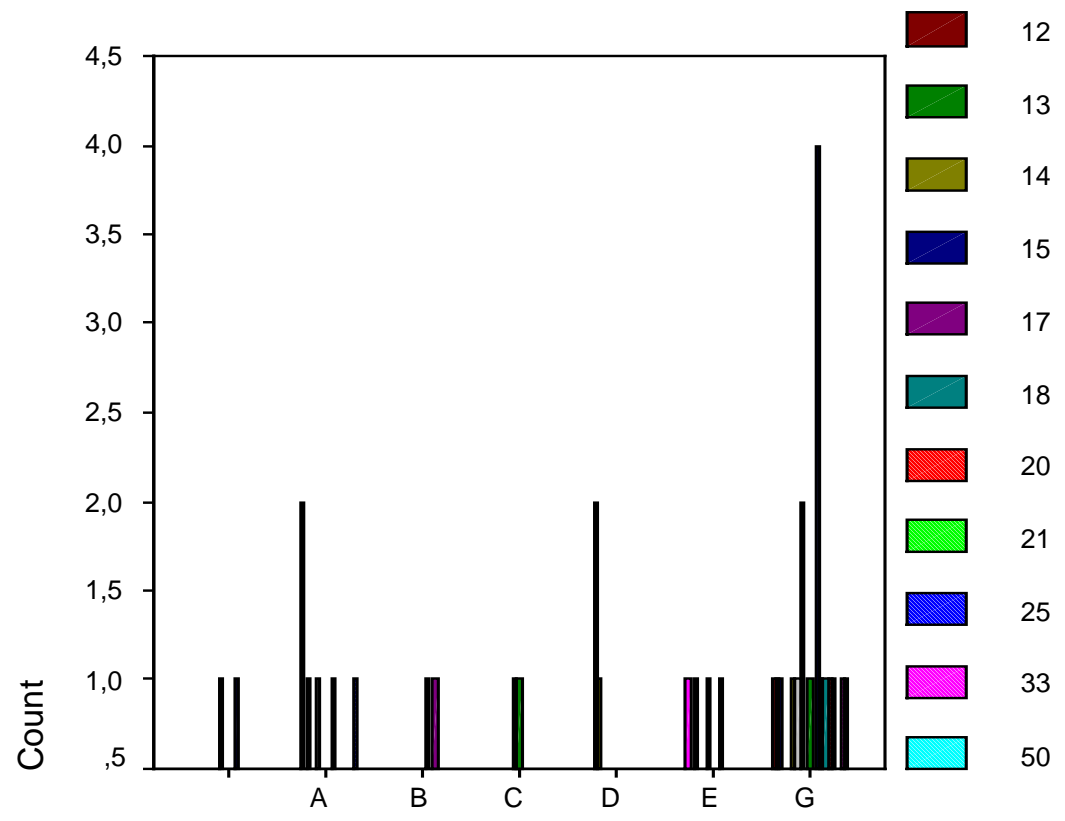

\section{HAMBAT}

Sumber: Data Olahan

Grafik 9: Analisis crosstabs antara Hambatan dan lama bekerja 


\section{Harapan kedepan}

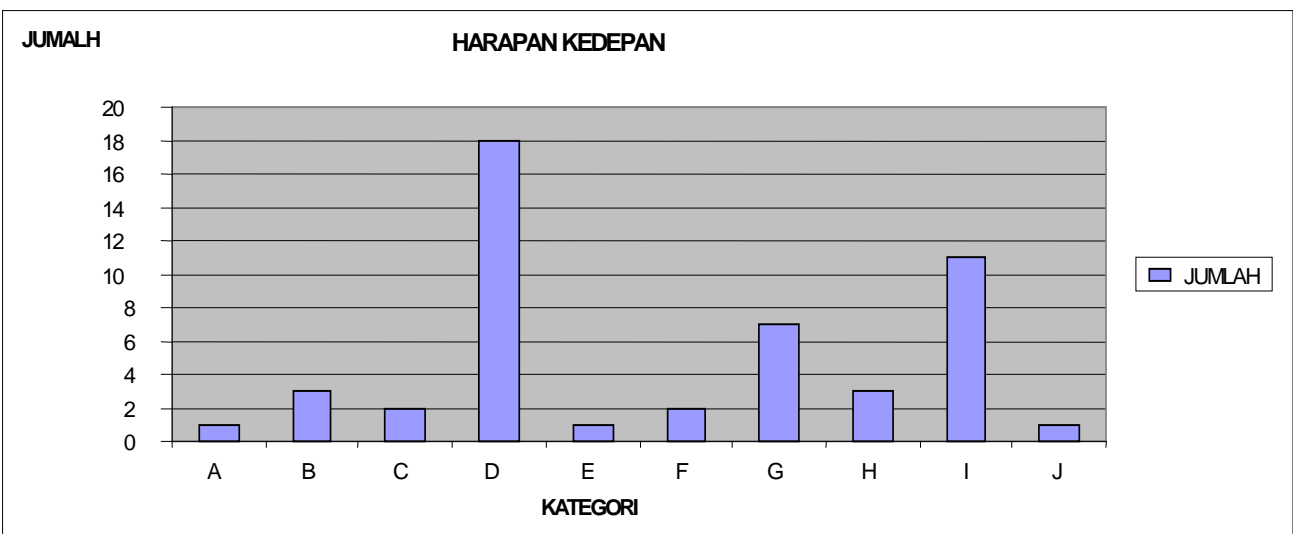

Sumber: data olahan

Grafik 10: Harapan ke Depan Women Co-Entrepreneur di Usaha Kerupuk Tuntang

Keterangan:

A : Bantuan DariPemerintah

B : Jadi Juragan

C : Membuka Lapangan Pekerjaan

D : Memperluas Pemasaran

E : Mempunyai Ijin Depkes

F : Meningkatkan Produksi

$\mathrm{G}$ : Pinjaman Lunak

H : Punya Mesin Sendiri

I : Skala Ndustri Diperluas

Harapan merupakan satu hal yang harus dimiliki oleh seorang entrepreneur untuk mengembangkan usahanya. Harapan para co entrepreneur ditunjukkan pada Grafik 10. Dari harapan mereka tampak terlihat jelas bahwa memperluas pemasaran dan memperluas skala industri merupakan hal yang terpenting untuk memajukan usahanya. Pemasaran yang mereka lakukan selama ini sebetulnya sudah cukup baik karena sudah bisa menjangkau Kalimantan, Sumatera, bahkan Sulawesi. Untuk itu mereka ingin melakukan penetrasi pasar yang sudah terlayani dan mencari sasaran daerah baru melalui ekstensifikasi pasar.

Departemen Perindustrian sudah banyak membantu dalam hal perijinan dan bantuan alat. Namun demikian, bantuan alat yang selama ini mereka dapatkan sering tidak berguna seperti mesin oven pengering. Hal ini diakibatkan mereka tidak mampu mengoperasionalkan dengan baik. Kalaupun bisa biaya produksinya jadi mahal karena menggunakan listrik. Padahal selama ini untuk pengering mereka mengandalkan alam (sinar matahari) yang biayanya lebih mudah. Dari persoalan ini, mereka mengharapkan peran Pemerintah Daerah untuk memberikan subsidi operasional mesin oven supaya harga krupuk bisa kompetitif di pasar dan kualitas produk menjadi meningkat. 


\section{PENUTUP}

\section{Kesimpulan}

Berdasarkan hasil analisis di atas dapat disimpulkan bahwa berkaitan dengan motivasi, keberhasilan tetangga yang sudah memulai bisinis terlebih dahulu memberikan motivasi bagi women co-entrepreneur meningkatkan kesejahteraan keluarga. Peran utama yang dijalankan oleh para women coentrepreneur di usaha kerupuk desa Tuntang ini adalah Produksi dan pengelolaan administrasi dan pembukuan.

Hambatan yang dialami selama ini berkaitan dengan mahalnya harga bahan baku dan musim, hal ini mengakibatkan mereka membutuhkan modal tambahan Harapan kedepan yang dimiliki oleh women co-entrepreneur adalah bagaimana mereka bisa memperluas pemasaran dan skala industri mereka.

\section{Saran}

Women Co-Entrepreneur di Tuntang perlu diberikan pelatihan yang diharapkan dapat membantu para women co-entrepreneur mengenai "Bagaimana menguatkan jiwa entrepreunership". Hal ini untuk mengatasi hamabatan yang mereka alami salama ini seperti menghadapi resiko berhutang untuk menambah modal. Dan pelatihan yang berkaitan dengan manajemen bisnis supaya dapat mengelola usaha (keuangan dan produksi) dan pasar lebih baik.

Sedangkan untuk penelitian mendatang dapat diteliti lebih jauh lagi tentang "Bagaimana perilaku Pengeloalan Keuangan yang selama ini mereka terapkan?” Untuk mensiasati mereka supaya dapat berhutang dengan rasa yang aman.

\section{DAFTAR PUSTAKA}

Anonymous (1998). Women co-entrepreneur in Europe. Danish Federation of Small and Medium Entreprises report. Danish Federation of Small and Medium Entreprise and Breakthrough, Greece.

Anonymous (2000). Pemberdayaan perempuan dalam Usaha Kecil dan Menengah 2000, Centre for Entreprise and Economic Development Research (CEEDR), Mildlesex Univesity Business School, London.

Baines S. and Wheelock j. (1998). Working for each other: gander, the Household and Microbusiness Survival and Growth. International Small Business Journal, 17 (1), 6-35.

Brown, B. (1989). Patners in Life ini also in Business, Wall Street Journal,New York, Dow Jones Co.

Lonescu, D. (1999). Women Entrepreneurship: Exchanging Experiences Between OECD and Transition Economy Countries, Brijuni Conference, LEED Programme OECD. October.

Marshack, K.J. (1993). Copreneur Couples literature review on Boundaries and transition among copreneur, Family Business Review, 6 (4), 355-359.

Marshall, K. (1999). Working Together Self employed couples, statistics Canada Perspectives, 9-13.

Muske G, Fitzgerald M.A. \& Kim J.E. (2002). Copreneurs as Family Business evaluating the difference by industry type, proceedings of the US Association for Small Business and Entrepreneurship, Annual Conference, April.

O’ Cannor, V., Hamauda, A., Henry, C. \& Johsonston (2003). Co-entrepreneural Venture: a study of mix gender founders of ICT companies in Ireland, Journal of Small Busi- 
Jurnal Siasat Bisnis Vol. 14 No. 1, April 2010 Hal: 43-58

ness and Enterprise Development, $13,600-619$.

Timmons, J.A. (1994). New Venture Creation: Entrepreneurship for the
21" Century, Irwin. Boston: McGraw-Hill/Irwin. 


\section{INDEXES}

\begin{tabular}{|l|l|}
\hline \multicolumn{1}{|c|}{ SUBJECT } & \multicolumn{1}{|c|}{ OBJECT } \\
\hline Anonymous & Pendididkan \\
Baines & Usia \\
Wheelock & Lama kerja \\
Brown, & Akses Modal \\
Emory & Women co-Entrepreneur \\
Cooper & motivasi \\
Garavan & peran \\
Ocinneide & hambatan \\
Lonescu & Tuntang \\
Marshack & Pemerintah \\
Marshall & Juragan \\
Muske & Lapangan Pekerjaan \\
Fitzgerald & Pemasaran \\
Kim & Depkes \\
O' Cannor & Produksi \\
Hamauda & Pinjaman Lunak \\
Henry & \\
Johsonston & \\
Timmons & \\
& \\
\hline
\end{tabular}

